\author{
Оригинальная статья / Original article \\ УДК 551.242 \\ DOI: http://dx.doi.org/10.21285/2686-9993-2020-43-4-486-498
}

\title{
Clockwise rotation of the Tarim basin driven by the Indian plate impact. Part II*
}

\author{
(c) Junmeng Zhao \\ aInstitute of Tibetan Plateau Research, Chinese Academy of Sciences, Beijing, China
}

\begin{abstract}
In the previous article ${ }^{\star *}$, data were given on the clockwise rotation of the Tarim Basin at a speed of $0.461^{\circ}$ per million years around a virtual axis within the structure. Additional fieldwork and new evidence confirm earlier findings about the asymmetry of the Indo-Asian collision zone. These data are additional arguments in favor of the rotation of the Tarim Basin and lithospheric interactions along the Tarim boundaries. Conclusions are based on detailed geological and geophysical data.
\end{abstract}

Keywords: Tarim Basin, block rotation, Indian plate, Eurasian plate, continental collision, paleoenvironment, westerly moisture pathway

For citation: Zhao Junmeng. Clockwise rotation of the Tarim basin driven by the Indian plate impact. Part II. Nauki o Zemle i nedropol'zovanie = Earth sciences and subsoil use. 2020;43(4):486-498. (In Russ.) https://doi.org/10.21285/2686-99932020-43-4-486-498

\section{Вращение Таримского бассейна по часовой стрелке под влиянием движения Индийской плиты. Часть II*}

\author{
(С) Цзюньмэн Чжао \\ аИнститут изучения Тибетского плато, Китайская академия наук, г. Пекин, Китай
}

\begin{abstract}
Резюме: В предыдущей статье ${ }^{\star *}$ были приведены данные о вращении Таримского бассейна по часовой стрелке со скоростью $0,461^{\circ}$ в миллион лет вокруг виртуальной оси внутри структуры. Дополнительные полевые исследования и новые фактические данные подтверждают сделанные ранее выводы об асимметрии зоны Индо-Азиатского столкновения. Эти данные являются дополнительными аргументами в пользу вращения Таримского бассейна и литосферных взаимодействий вдоль границ Тарима. Выводы базируются на детальных геолого-геофизических данных.
\end{abstract}

Ключевые слова: Таримский бассейн, вращающиеся блоки, Индийская плита, Евразийская плита, континентальная коллизия, палеогеография, западный водный канал

Для цитирования: Чжао Цзюньмэн. Вращение Таримского бассейна по часовой стрелке под влиянием движения Индийской плиты. Часть II. Науки о Земле и недропользование. 2020. Т. 43. № 4. С. 486-498. https://doi.org/10.21285/2686-9993-2020-43-4-486-498

\footnotetext{
* The article was provided by the Earth Science Frontiers journal within the framework of the agreement between the editorial boards of Irkutsk National Research Technical University (Irkutsk, Russia) and China University of Geosciences (Beijing, China) on the exchange of open access scientific papers.

* Статья была предоставлена редакцией журнала Earth Science Frontiers в рамках соглашения между редакциями Иркутского национального исследовательского технического университета (г. Иркутск, Россия) и Китайского геологического университета (г. Пекин, Китай) об обмене научными статьями открытого доступа.

${ }^{* *}$ This is the continuation of the article: Zhao Junmeng, Zhang Peizhen, Yuan Xiaohui, Gan Weijun, Sun Jimin, Deng Tao, et al. Clockwise rotation of the Tarim basin driven by the Indian plate impact. Earth sciences and subsoil use. 2019;42(4):425-436. https://doi.org/10.21285/2686-9993-2019-42-4-425-436

** Данная статья является продолжением статьи: Чжао Цзюньмэн, Чжан Пэйчжэнь, Юань Сяохуй, Гань Вэйцзюнь, Сунь Цзиминь, Дэн Тао [и др.]. Вращение Таримского бассейна по часовой стрелке под влиянием движения Индийской плиты. Науки о Земле и недропользование. 2019. Т. 42. № 4. С. 425-436. https://doi.org/10.21285/2686-9993-2019-42-4$425-436$
} 


\section{Four profiles crossing Tarim basin and its surrounding mountains}

The outcome of the paper is based mainly on four seismic profiles traversing diverse parts of the boundary zones of the Tarim Basin, that is, the XB Line in the north, the KJ Line in the northeast, the BD Line in the east, and the ANTILOPEI line in the south. The locations of the profiles are shown in Fig. S1 and Fig. $1^{* * *}$. Results of the XB, $B D$, and ANTILOPE-I lines are published in Zhao et al. [1-3]. The $\mathrm{KJ}$ line is the most recent profile. Compared with previous profiles, the new data from the KJ line revealed a complex lithospheric configuration of the Tarim Baisin boundaries, which motivated further examination of the plate kinematics and the (clockwise) rotation of the basin. Here we briefly summarize the relevant results of the four profiles, which are closely related to the topic of the present paper.

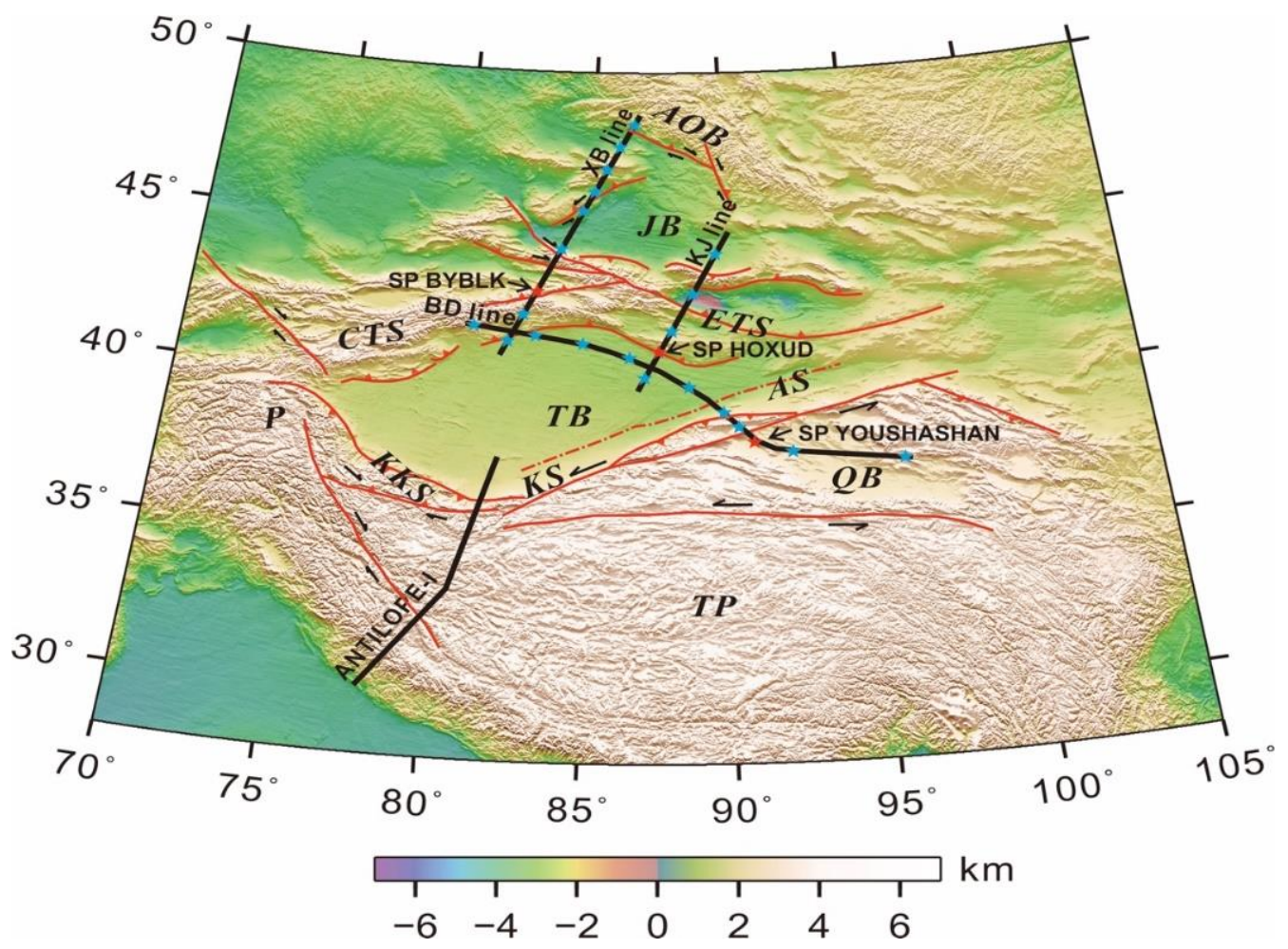

Fig. S1. Map of profile locations

Black lines denote the profile locations. Red lines indicate faults. Stars along each profile stand for the shot points, with the red one showing the relation between the Tarim basin and its surounding mountains by seismic records, traveling time fitting, amplitude fitting and ray tracing

TP - Tibetan Plateau; TB - Tarim Basin; QB - Qaidam Basin; JB - Junggar Basin; AOB - Altai Orogenic Belt; CTS - Central Tien Shan; ETS - Eastern Tien Shan; AS - Altyn Tagh Shan; KS - Kunlun Shan; KKS - Karakorum Shan

\section{Puc. S1. Карта расположения профилей}

Черными линиями обозначено расположение профилей. Красные линии указывают на разломы.

Голубые звездочки вдоль каждого профиля обозначают очаги сейсмического взрыва, красные звездочки демонстрируют связь между Таримским бассейном и окружающими его горами с помощью сейсмограмм, построения кривых времени пробега, амплитуды и трассировки лучей

TP - Тибетское плато; ТВ - Таримский бассейн; QВ - бассейн Кайдам; ЈB - Джунгарский бассейн;

AOB - Алтайский орогенный пояс; CTS - Центральный Тянь-Шань; ETS - Восточный Тянь-Шань; AS - Алтынтаг (Алтыншань); KS - Куньлунь; KKS - Каракорум

\footnotetext{
*** The authors invite to compare the illustrative material in this article with the figures from the previous article "Clockwise rotation of the Tarim basin driven by the Indian plate impact". The differentiation of the illustrative material of this article under figure numbering is performed using additional literals.

*** Авторы предлагают сравнить иллюстративный материал в данной статье с рисунками из предыдущей статьи «Вращение Таримского бассейна по часовой стрелке под влиянием движения Индийской плиты». Для возможности разграничения иллюстративного материала при нумерации рисунков в этой статье были дополнительно использованы литеры.
} 
$X B$ line. From the northern margin of the Tarim Basin (TB) $\left(82^{\circ} 52^{\prime} 28^{\prime \prime} \mathrm{E}, 41^{\circ} 02^{\prime} 34^{\prime \prime} \mathrm{N}\right)$ to the southern foot hills of the Altay Orogenic Belt (AOB) $\left(86^{\circ} 46^{\prime} 19.2^{\prime \prime} \mathrm{E}, 48^{\circ} 56^{\prime} 00^{\prime \prime} \mathrm{N}\right)$, the XB Line is $995 \mathrm{~km}$ long and crosses northern part of the Tarim Basin, the Tien Shan Orogenic Belt, the Junggar Basin (JB), and the Altai Orogenic Belt (Fig. 1 and Fig. S1). During the original study, Zhao et al. [1] obtained a 2D velocity structure by seismic reflection / refraction profiling, a 2D density structure from modeling gravity data, the detailed structure of the crust-mantle transitional zone using wavelet transforms of the deep seismic sounding (DSS) data, and a 2D electrical resistivity structure using magnetotelluric (MT) sounding. They also studied focal mechanisms and tectonic processes. With this comprehensive set of geological and geophysical data, a geodynamic model was obtained for this region ([1], also shown in Fig. S2). The results suggest that the Tarim Basin subducts northward beneath the
Tien Shan orogenic belt, while the Junggar Basin contacts the Tien Shan in a pattern of strike-slip mode (Fig. 2, $a$ and Fig. S2).

Evidence for the northward subduction of the Tarim Basin beneath the Tien Shan orogenic belt can be seen in detail with an example of a shot gather (shot point SP Byblk, located at 218.217 $\mathrm{km}$ along the profile). Two Moho reflection phases can be clearly observed (Fig. S3, a) and modeled (Fig. S3, $b-d$ ). The upper one is the Moho of the Tien Shan Orogenic Belt, and the lower one is the Moho of the Tarim Basin.

KJ Line. Recently, we have conducted a comprehensive geophysical profile from Korla to Jimsar (KJ line). From the northern margin of the Tarim basin $\left(82^{\circ} 52^{\prime} 28^{\prime \prime} \mathrm{E}, 41^{\circ} 02^{\prime} 34^{\prime \prime} \mathrm{N}\right)$ to the southern margin of the Junggar basin $\left(86^{\circ} 46^{\prime} 19.2^{\prime \prime} \mathrm{E}\right.$, $\left.48^{\circ} 56^{\prime} 00^{\prime \prime} \mathrm{N}\right)$, the profile is $600 \mathrm{~km}$ long and crosses the northern margin of the Tarim basin, the Tien Shan, and the southern margin of the Junggar basin (Fig. S1).

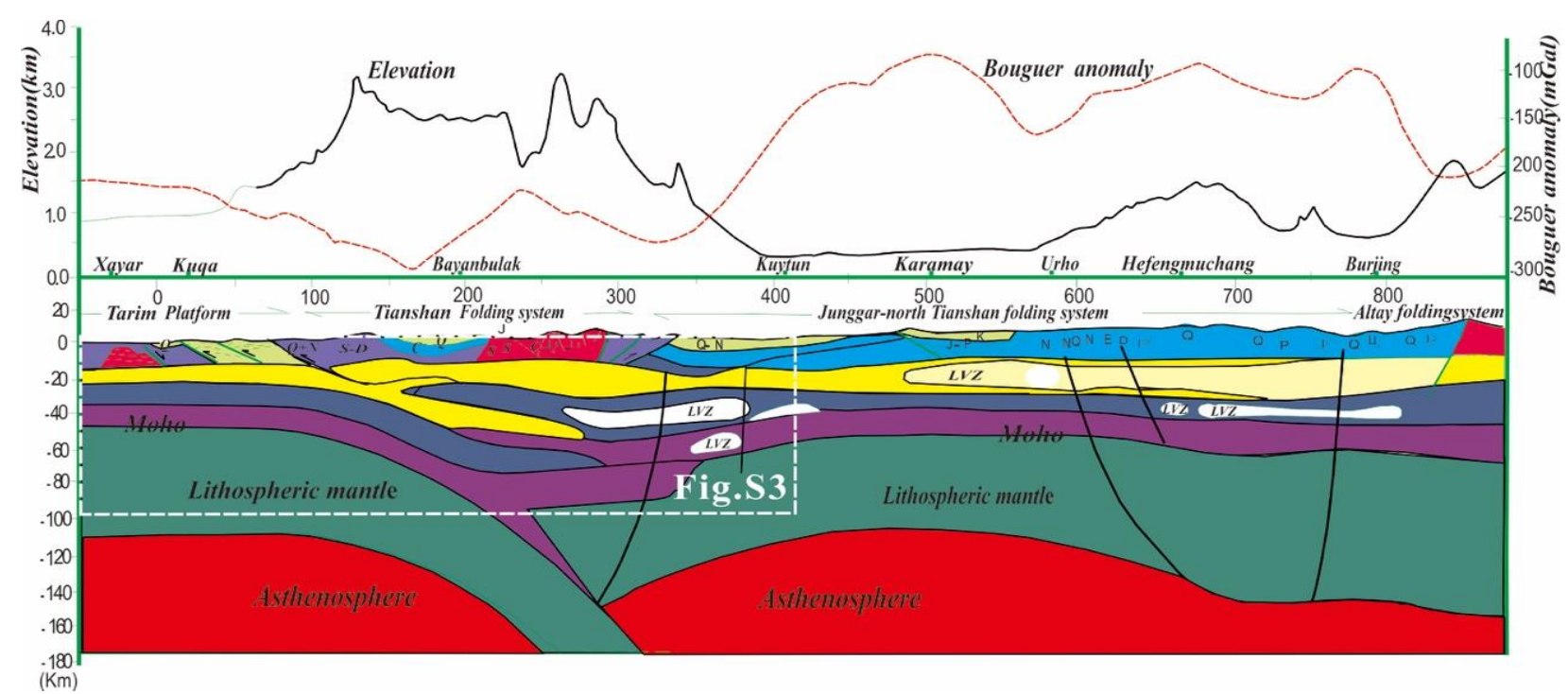

Fig. S2. Structure of the crust and mantle lithosphere along the XB line

The upper panel shows the elevation (solid line) and Bouguer anomaly (dotted line). The lower panel shows the lithospheric structures. The box and the star mark the location of the seismic section and the shot point shown in Fig. S3. LVZs represent low velocity zones. The solid lines are interfaces determined by deep seismic sounding, MT sounding and gravitational inversion. The dashed lines are inferred interfaces. Lines of high angles are faults determined by seismic sounding, MT sounding and gravitational analyses. The complicated crust-mantle transitional zone beneath the Tien Shan orogenic belt is determined by using wavelet transform [1]

Puc. S2. Строение земной коры и литосферной мантии по линии ХВ

В верхней части рисунка представлено поднятие (сплошная линия) и аномалия Буге (пунктирная линия). Нижняя часть рисунка демонстрирует литосфрерные структуры. Рамкой и звездочкой отмечено местоположение сейсмического разреза и очага сейсмического взрыва, показанного на рис. S3.

LVZ - это зоны низких скоростей. Сплошными линиями отмечены границы раздела, которые определены глубинным сейсмическим зондированием, магнитотеллурическим зондированием и гравитационной инверсией. Пунктирными линиями обозначены предполагаемые границы. Крутонаклоненные линии обозначают разломы, определенные сейсморазведкой, магнитотеллурическим зондированием и гравитационным анализом. Сложная переходная зона коры в мантию, расположенная под орогенным поясом Тянь-Шаня, определена с помощью вейвлет-преобразования [1] 
Чжао Цзюньмэн. Вращение Таримского бассейна по часовой стрелке под влиянием... Zhao Junmeng. Clockwise rotation of the Tarim basin driven by the Indian plate impact. Part II

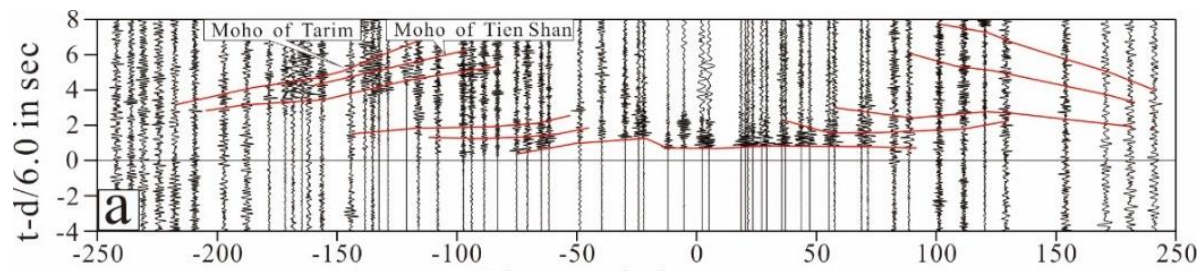

Distance in $\mathrm{km}$

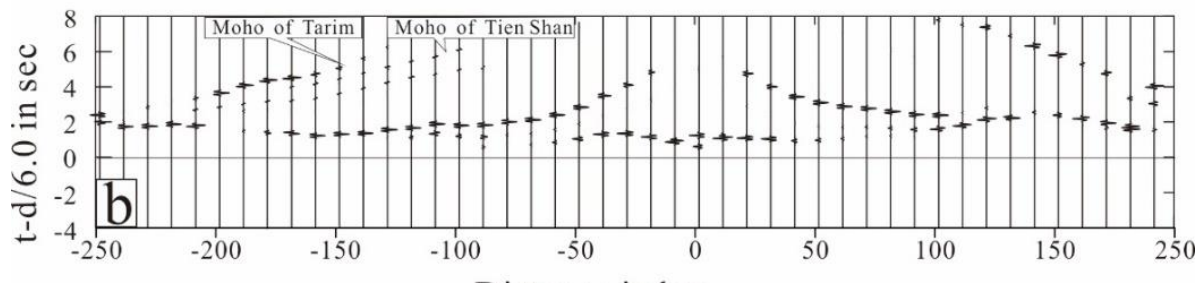

Distance in $\mathrm{km}$
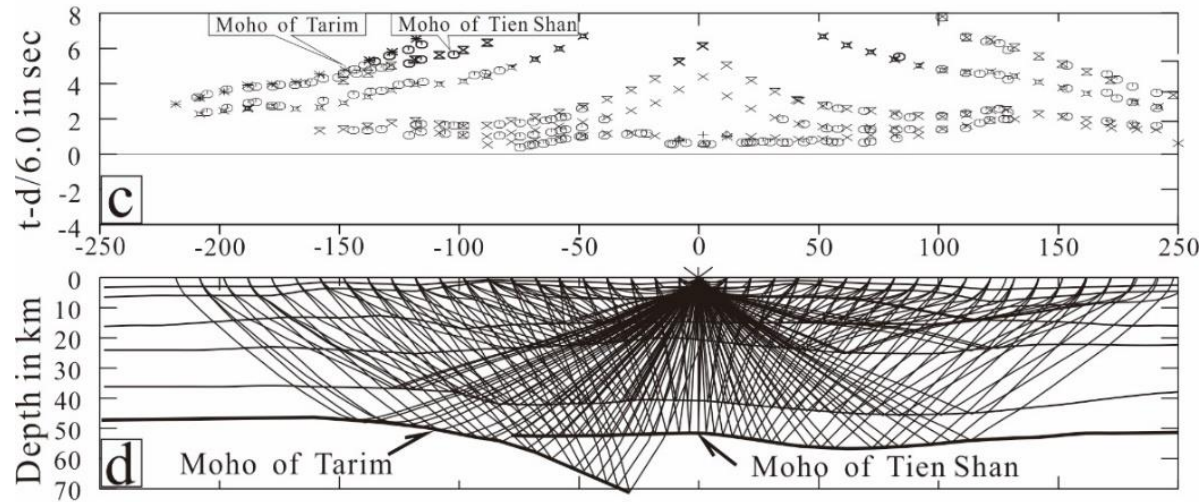

Distance in $\mathrm{km}$

\section{SP BYBLK $(218 \mathrm{~km})$}

Fig. S3. Data and modeling example for SP Byblk:

a - Seismic records of SP Byblk: The shot point $(a t) \mathrm{km}$ ) is located in the southern part of the Tien Shan orogenic belt (see Fig. S2 for the SP location) and the receivers are set up in the northern margin of the Tarim basin, the Tien Shan orogenic belt and the southern margin of the Junggar basin. All recorded seismic signals came from the same shot point at the same moment. The horizontal axis indicates offset distance from the shot point. The vertical axis indicates travel time reduced by $6 \mathrm{~km} / \mathrm{s}$. A 1-20 Hz bandpass filter and automatic gain control with 2-s window were applied. The thick solid lines show the identified effective seismic phases. The thin horizontal streight line at time of $0 \mathrm{~s}$ is a reference line.

Travel times of all observed phases constitute the input data for ray tracing and synthetic seismogram

$b$ - Calculated theoretical amplitude: The vertical axis indicates travel time reduced by $6 \mathrm{~km} / \mathrm{s}$ $c$ - Travel time fitting: The vertical axis indicates travel time measured (marked with $\mathrm{O})$ and calculated (crosses), reduced by $6 \mathrm{~km} / \mathrm{s}$

$d$ - Ray tracing: The vertical axis indicates depth in $\mathrm{km}$. The thick lines are interfaces determined by modeling of the seismic phases. The distance axis is referenced to the shot point in (a) and to the entire XB line in (b-d)

Puc. S3. Данные и пример моделирования очага сейсмического взрыва Быблк:

а - сейсмограммы очага сейсмического взрыва Быблк. Точка взрыва (0 км) расположена в южной части орогенного пояса Тянь-Шаня (местоположение очага сейсмического взрыва см. на рис. S2), сейсмоприемники

расположены по северному краю Таримского бассейна, орогенного пояса Тянь-Шаня и южной окраины Джунгарского бассейна. Все зарегистрированные сейсмические сигналы пришли из одного и того же очага сейсмического взрыва в один и тот же момент. Горизонтальная ось показывает расстояние между очагом сейсмического взрыва и приемником. Вертикальная ось показывает скорость распространения, уменьшенную на 6 км/с. Были применены пропускающий полосовой фрильтр 1-20 Гц и автоматическая регулировка усиления амплитуд с двухсекундным окном. Жирные сплошные линии обозначают выявленные действующие сейсмические фазы. Тонкая прямая горизонтальная линия в момент 0 с является исходной линией отсчета. Время пробега всех наблюдаемых фаз является исходными данными для трассировки лучей и синтетической сейсмограммы b- расчетная теоретическая амплитуда. Вертикальная ось показывает время пробега, уменьшенное на 6 км/c c- построение кривых времени пробега. Вертикальная ось показывает измеренное время пробега (О) и расчетное время пробега (отмечено крестиками), уменьшенное на $6 \mathrm{~km} / \mathrm{c}$

$d$ - трассировка лучей. Вертикальная ось показывает глубину в километрах. Жирные линии обозначают границы, определенные моделированием сейсмических фаз. Ось расстояния привязана к очагу взрыва на графике (a) и ко всей линии ХВ на графиках (b-d) 
We obtained a 2D velocity structure from seismic reflection / refraction profiling, a 2D density structure and 2D geomagnetic intensity structure from joint inversion of the gravity anomaly with the geomagnetic anomaly. In contrast with the XB line, no evidence of crustal underthrusting can be found along the KJ line beneath the northern margin of the Tarim basin. In contrast, the results suggest that the Tarim Basin moves away from the Tien Shan Orogenic belt, and the Junggar Basin subducts southward beneath the Tien Shan orogenic belt, as shown in Fig. 2, b and Fig. S4.

The spatial separation of Tarim Basin and the Tien Shan orogenic belt can be seen in detail in Fig. S5. The shot point SP Hoxud is located at $177 \mathrm{~km}$. Modeling seismic records shows that there exists a gap and dislocation between the Tarim Moho and Tien Shan Moho, implying that the Tarim Basin is moving from the Tien Shan, leaving a lateral gap between the two Mohos.

$B D$ Line. Here we present the results of a 1420-km-long seismic refraction / wide-angle-reflection profile (BD Line) that crosses from NW to SE the northern margin of the Tarim basin, the east central Tarim basin, the Altyn Tagh Range, and the northern Qaidam basin (Fig. 1). The 2D velocity structure along the $B D$ Line as shown in Fig. S6 was obtained from the modeling of the seismic data as mentioned above. The results indicate that the Tarim Basin has subducted beneath the Altyn Tagh Range, as shown in Fig. 2, $c$ and Fig. S7 for detail.

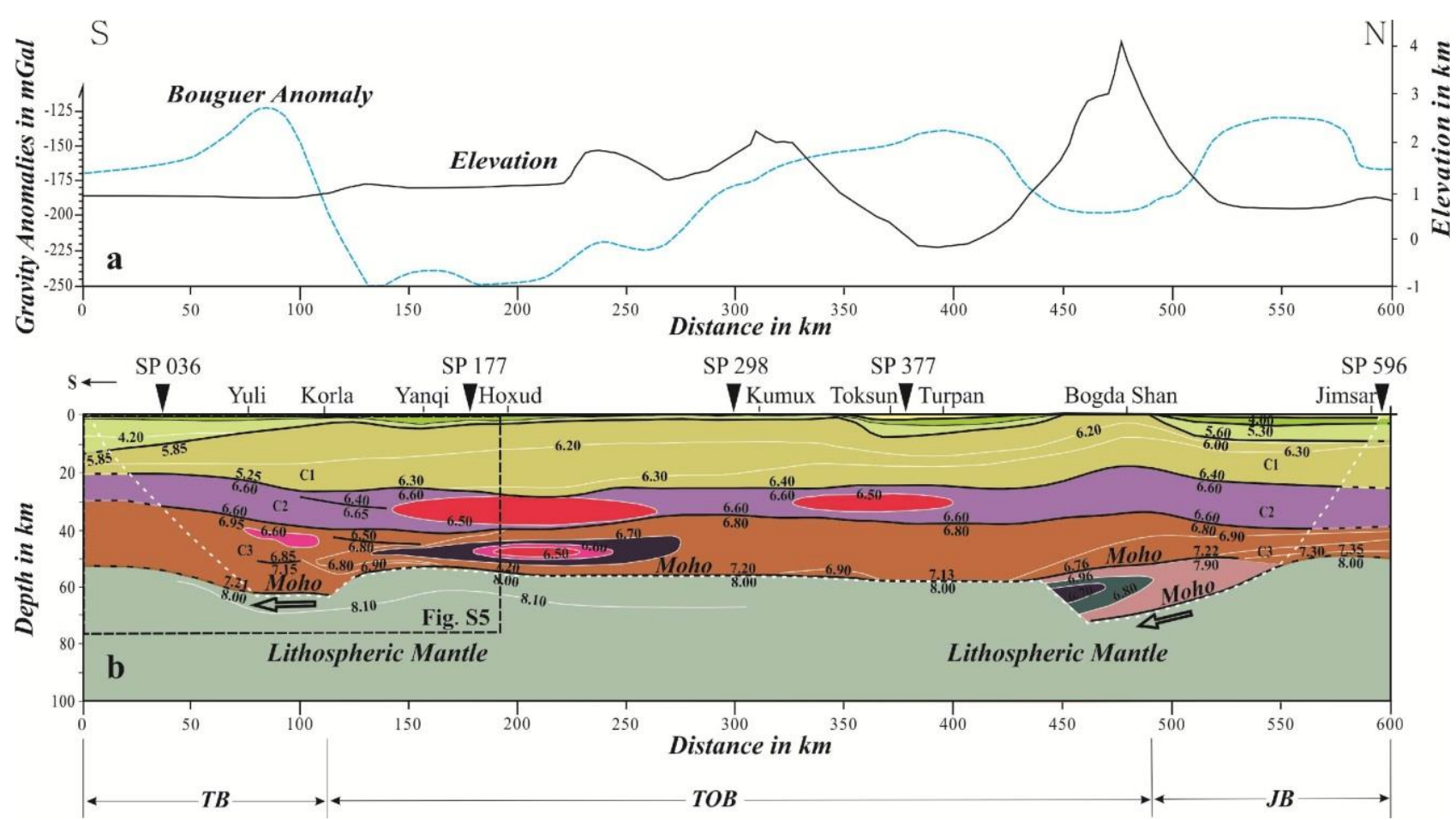

Fig. S4. Crustal structure along KJ line:

a - Elevation (black solid line) and Bouguer anomaly (blue dotted line) along the KJ line $b$ - Lithospheric structure and geodynamic model. Solid lines are interfaces determined by deep seismic sounding and joint inversion of gravity and geomagnetism. Vertical triangles at surface denote shots. Arrows below the Moho indicate Moho movement direction. The thin dotted lines are velocity contours TB - Tarim Basin; TOB - Tien Shan Orogenic Belt; JB - Junggar Basin

The box and the star mark the location of the seismic section and the shot point, respectively, shown in Fig. S5 Puc. S4. Строение земной коры по линии Корла-Джимсар (KJ):

a - поднятие (черная сплошная линия) и аномалия Буге (синяя пунктирная линия) по линии KJ b- строение литосферы и геодинамическая модель. Сплошные линии обозначают границы, определенные глубинным сейсмическим зондированием и совместной инверсией силы тяжести и геомагнетизма. Вертикальные треугольники на поверхности обозначают очаги сейсмических взрывов. Стрелки под Мохо (Moho) указывают направление движения Мохо. Тонкими пунктирными линиями обозначены изолинии скорости TВ - Таримский бассейн; ТОВ - орогенный пояс Тянь-Шаня; ЈВ - Джунгарский бассейн

Рамочка и звездочка обозначают соответственно местоположение сейсмического профиля и очага взрыва, показанных на рис. S5 
Чжао Цзюньмэн. Вращение Таримского бассейна по часовой стрелке под влиянием...
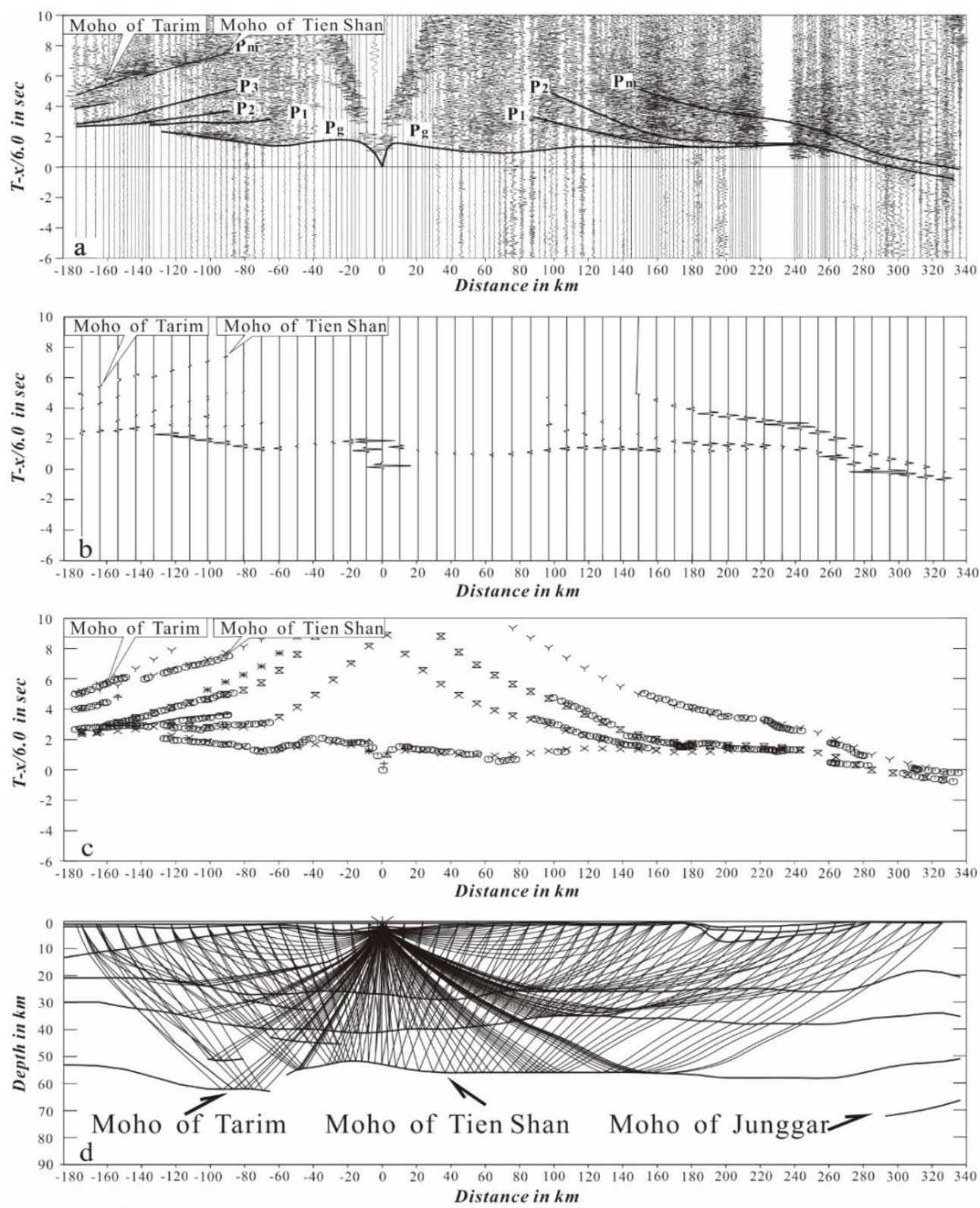

SP HOXUD $(177 \mathrm{~km})$

Fig. S5. Data and modeling example for SP Hoxud

The shot point (at $0 \mathrm{~km})$ is located in the southern part of the Tien Shan orogenic belt and the receivers are set up in the northern margin of the Tarim basin, the Tien Shan orogenic belt and the southern margin of the Junggar basin.

Locations of the shot and the seismic section are indicated in Fig. S4. The horizontal axis indicates offset distance from the shot point. Presentation (panels a-d) is the same as described in Fig. S3

Puc. S5. Данные и пример моделирования очага сейсмического взрыва Хоксуд

Очаг сейсмического взрыва (0 км) расположен в южной части орогенного пояса Тянь-Шаня, приемники установлены по северному краю Таримского бассейна, в орогенном поясе Тянь-Шаня и на южной окраине

Джунгарского бассейна. Расположение очага взрыва и сейсмического профиля показано на рис. S4.

Горизонтальная ось показывает расстояние между очагом сейсмического взрыва и приемником.

Описание графриков (a-d) такое же, как для рис. S3

ANTILOPE-I. The ANTILOPE-I profile is a broadband passive-source seismic array traversing western Tibet and southern Tarim Basin. It consisted of about 80 stations, operated from October 2006 to November 2007. During one year operation time, 478 teleseismic earthquakes of high signal / noise ratio were recorded and used for receiver function analysis [3]. A total number of $3476 \mathrm{~S}$ receiver functions (including SKS receiver functions from 249 events at epicentral distances of $60-115^{\circ}$ ). 


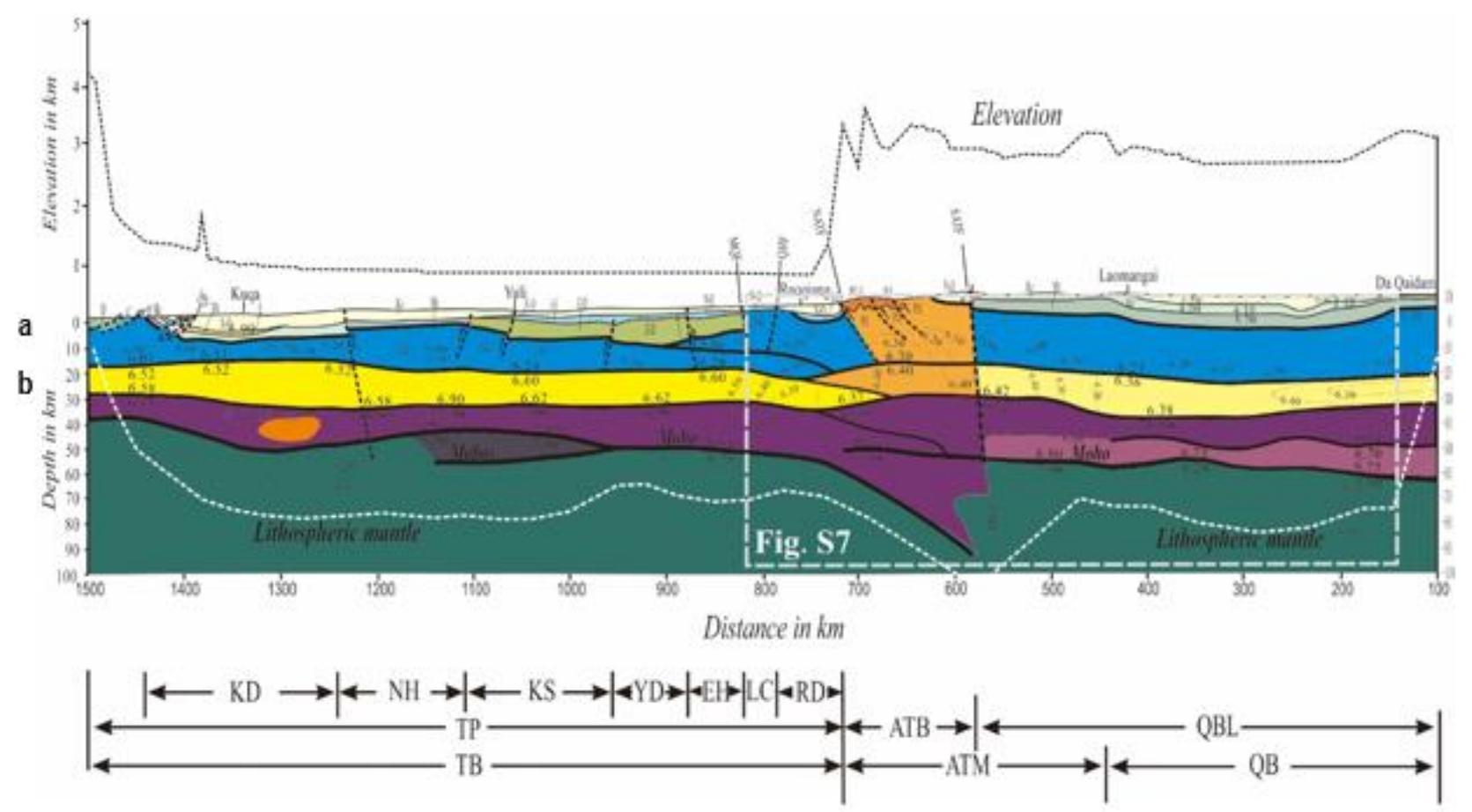

Fig. S6. Crustal and upper-mantle cross-section along the BD line across the east-central Tarim basin, Altyn Tagh Range and Qaidam basin [2]:

a - Tectonic setting and topography;

$b$ - Crustal structure derived from the seismic velocity structure using laboratory measurements of seismic velocities for a wide suite of rock types

The box marks the location of the seismic section shown in Fig. S5. The respective shot point is highlighted

Puc. S6. Разрез земной коры и верхней части мантии по линии BD в восточно-центральной части Таримского бассейна, горного хребта Алтын Таг и Кайдамского бассейна [2]: а - тектоническая обстановка и топография;

b - структура земной коры, полученная из структуры сейсмической скорости, определенной в результате лабораторных измерений сейсмических скоростей широкого спектра типов горных пород Рамочкой отмечено местоположение сейсмического профиля, показанного на рис. S5. Соответствующий очаг сейсмического взрыва выделен

In the $S$ receiver function image (Fig. S8), the Moho can be identified along the profile A Moho step can be observed beneath the border from the Tibetan plateau to the Tarim Basin. No evidence of crustal underthrusting can be identified.

\section{GPS Data and strategy}

The main part ( $55 \%$ ) of GPS velocities are from the published solutions of two Chinese national scientific projects, Crustal Movement Observation Network of China (CMONOC-I) and Tectonic and Environmental Observation Network of Mainland China (CMONOC-II) [4]. The detailed GPS observation methods and data processing strategies were introduced by Li et al. [4]. In addition to the GPS velocity data set of 240 stations from CMONOC (around the Tarim Basin but within the territory of China), we merged another published GPS velocity data set of 202 stations (around the western Tarim Basin) from
Zubovich et al. [5] to enhance the density and coverage of GPS stations.

Although the CMONOC velocities and those of another data set are given in Eurasia-fixed reference frames, their frames may differ slightly from each other. As these two data sets shared some stations with the CMONOC data set, we used stations common to the CMONOC data set as "links" to transform all the other velocities into the same reference frame as that for CMONOC by using rigid-body rotations with appropriate angular velocity (Euler vector). After the reference frame transformations, the maximum differences of north and east components of the velocities for the same stations in different data sets are 2.6 and $2.2 \mathrm{~mm} / \mathrm{yr}$, respectively; these values are within 2 standard deviations of the velocity components. The final velocities of the common stations are the weighted average of the values from all the data sets in the same Eurasia-fixed 

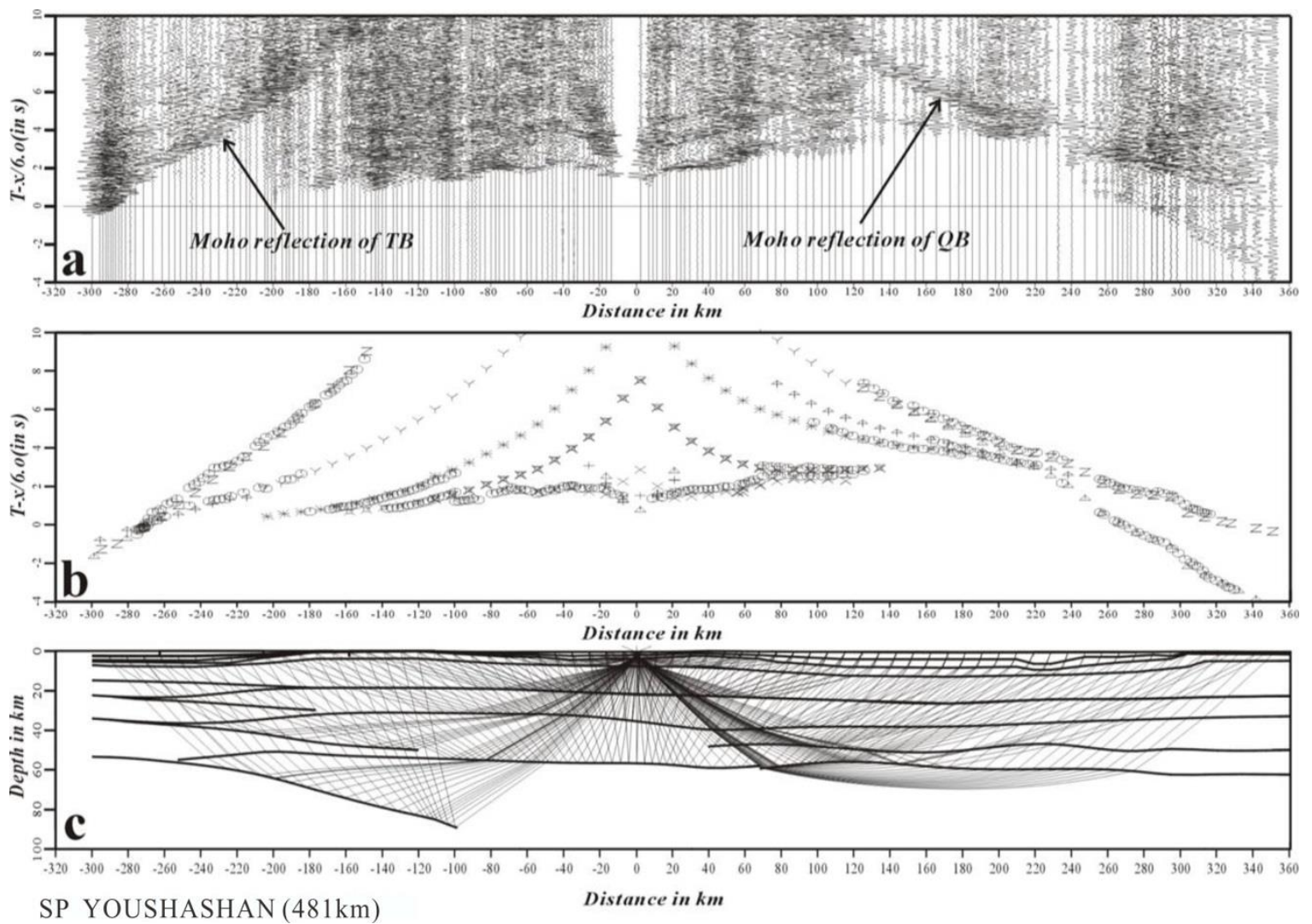

Fig. S7. Data and modeling example for shot point 8 (Youshashan)

The shot point (at $0 \mathrm{~km}$ ) is located south of the Altyn Tagh fault in the Qaidam basin (see Fig. S6 for the SP location). The receivers were located in the Tarim basin, Altyn Tagh Range, and Qaidam basin.

The horizontal axis indicates offset distance from the shot point ATR - Altyn Tagh Range; QB - Qaidam Basin [2]

Puc. S7. Данные и пример моделирования точки 8 сейсмического взрыва (Юшашань)

Очаг взрыва (в 0 км) расположен к югу от разлома Алтын Таг в Кайдамском бассейне (см. местоположение очага взрыва на рис. S6). Приемники расположены

в Таримском бассейне, горном хребте Алтын Таг и Кайдамском бассейне.

Горизонтальная ось показывает расстояние между очагом сейсмического взрыва и приемником ATR - горный хребет Алтын Таг; QB - Кайдамский бассейн [2]

reference frame. The combined velocities of 442 GPS stations in a Eurasia-fixed reference frame demonstrate the western Tarim regions are dominated by N-S direction while eastern Tarim moves toward the NE (Fig. 3, a).

In order to highlight the relative motion of Tarim Basin with respect of its surroundings, we used the following strategy to transform the GPS velocity field into a special "Tarim surrounding vicinity fixed reference frame". Firstly, we solved for the angular velocity of rigid-body rotation on Earth sphere that minimized the RMS velocity of all these surrounding stations. Then, by reversely rotating the whole GPS velocity field of the Tarim basin with the above angular velocity, we removed the overall rigid rotation of the surrounding vicinity of the Tarim Basin. This is equivalent to converting the original GPS velocity field relative to the Eurasia-fixed reference frame to the "Tarim surrounding vicinity fixed reference frame".

\section{The geodynamic source} of the rotation of the Tarim plate

Tibetan plateau is made up of three plates: the rigid Indian plate in the south, the rigid Asia plate in the north and a giant crush zone - Tibet "plate" sandwiched between the two. The giant crush zone with a horn-like shape facing east is featured high temperature (temperature is higher by $\sim 300^{\circ} \mathrm{K}$ than both the India plate and Eurasian plate) and low velocity (S wave velocity is lower by $5 \%$ than the two plates on its both sides), and high Sn wave attenuation (on top of the upper mantle the Sn wave almost disappears) and strong seismic anisotropy, hence it must be softer. It can be seen from Fig. S9 that the collision 


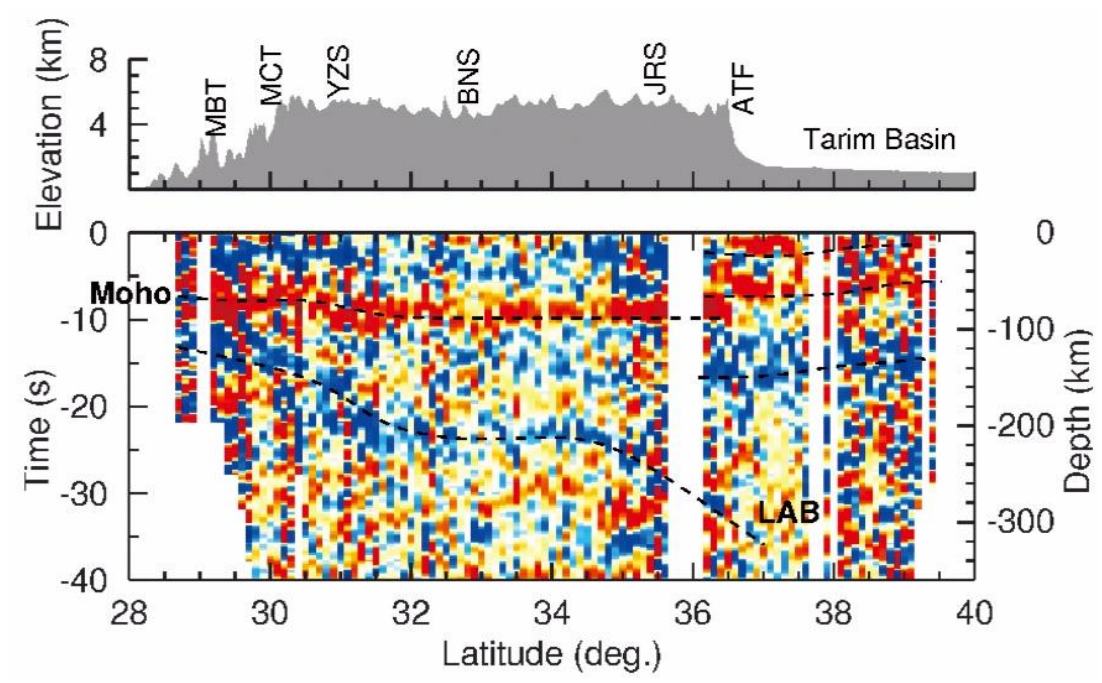

Fig. S8. S receiver functions, sorted by piercing points at the $150 \mathrm{~km}$ conversion depth [3]

Positive amplitudes are coded red, indicating an increasing velocity jump with depth; negative amplitudes are coded blue, indicating a negative velocity jump with depth. The Moho and LAB phases are marked by dashed lines.

The elevation is plotted at the top of each section, along with the position of the major sutures and faults. The Indian $L A B$ is deepening from about $100 \mathrm{~km}$ depth in northern India to about $200 \mathrm{~km}$ depth below the JRS at the ANTILOPE-I.

The Asian $L A B$ is only slightly south dipping from about 120 to $140 \mathrm{~km}$ at the profile. There are weak indications at the profile that the Asian $L A B$ might continue some distance in south direction above the Indian $L A B$

Puc. S8. Функции S-приемника, классифицированные по точкам проникновения на глубине преобразования в 150 км [3]

Положительные амплитуды обозначены красным цветом, указывающим на возрастание скорости с увеличением глубины; отрицательные амплитуды обозначены синим иветом, указывающим на возрастание отрицательной скорости с увеличением глубины. Пунктирными линиями отмечены фразы Moхо (Moho) и LAB. Высота подъема отображается в верхней части каждой секции вместе с положением основных тектонических швов и разломов. Индийский LAB углубляется примерно на 100 км в северной Индии и до 200 км вглубь под JRS на профиле ANTILOPE-I. Азиатский LAB имеет небольшой уклон по профрилю к югу от 120 до 140 км.

На профриле есть слабые признаки того, что азиатский LAB может простираться на некоторое расстояние в южном направлении над индийским $L A B$

between The Indian plate and the Asian plate occurred mainly at the southwest corner of the Tarim Basin, and a torque was generated in the Tarim plate, making the Tarim plate rotate clockwise. To the east, the Tibetan "plate", which is soft between the Indian plate and the Asian plate, has strong internal deformation under the stress background of the south-north compression, transmitting the stress to the west. Therefore, under the impact of the Indian plate, the Tarim plate would rotate clockwise on the one hand and translate from south to north on the other hand.

\section{Eocene and Oligocene mammalian faunas from the Junggar basin and the Mongolian plateau}

Changes in faunal compositions reveal distinct differences in biological evolution of the Junggar basin nearby the Tarim basin, and the Mongolian plateau, more than $1000 \mathrm{~km}$ farther east, but with the same latitude (Fig. S10).
The above arguments in favor of the character of rotation of the Tarim Basin are confirmed by the analysis of the distribution of the Eocene-Oligocene Mammalian fauna. There are data from various sources.

Late Eocene, Junggar basin [7] includes the Keziletuogayi A3 Fauna Insectivora, Fam. et gen. indet., Lagomorpha, Ochotonidae, Desmatolagus sp. Rodentia, Cylindrodontidae, Ardynomys vinogradovi Ardynomys sp., Dipodidae Allosminthus sp., Perissodactyla, Brontotheriidae Gen. et sp. indet., Paraceratheiinae Gen. et sp. indet., Amynodotinae Gen. et sp. indet., Cadurcodon cf. ardynensis, Gigantamynodon giganteus, Rhinocerotidae Gen. et sp. indet.

Early Oligocene, Junggar basin [7] includes the Keziletuogayi A1-2 Fauna Marsupia, Peradectidae, Junggaroperadectes burqinensis, Insectivora, Changlelestidae, Tupaiodon cf. morrisi, Erinaceidae, Palaeoscaptor cf. acridens, Lagomorpha, Ochotonidae, Desmatolagus sp., Rodentia, 
Чжао Цзюньмэн. Вращение Таримского бассейна по часовой стрелке под влиянием...

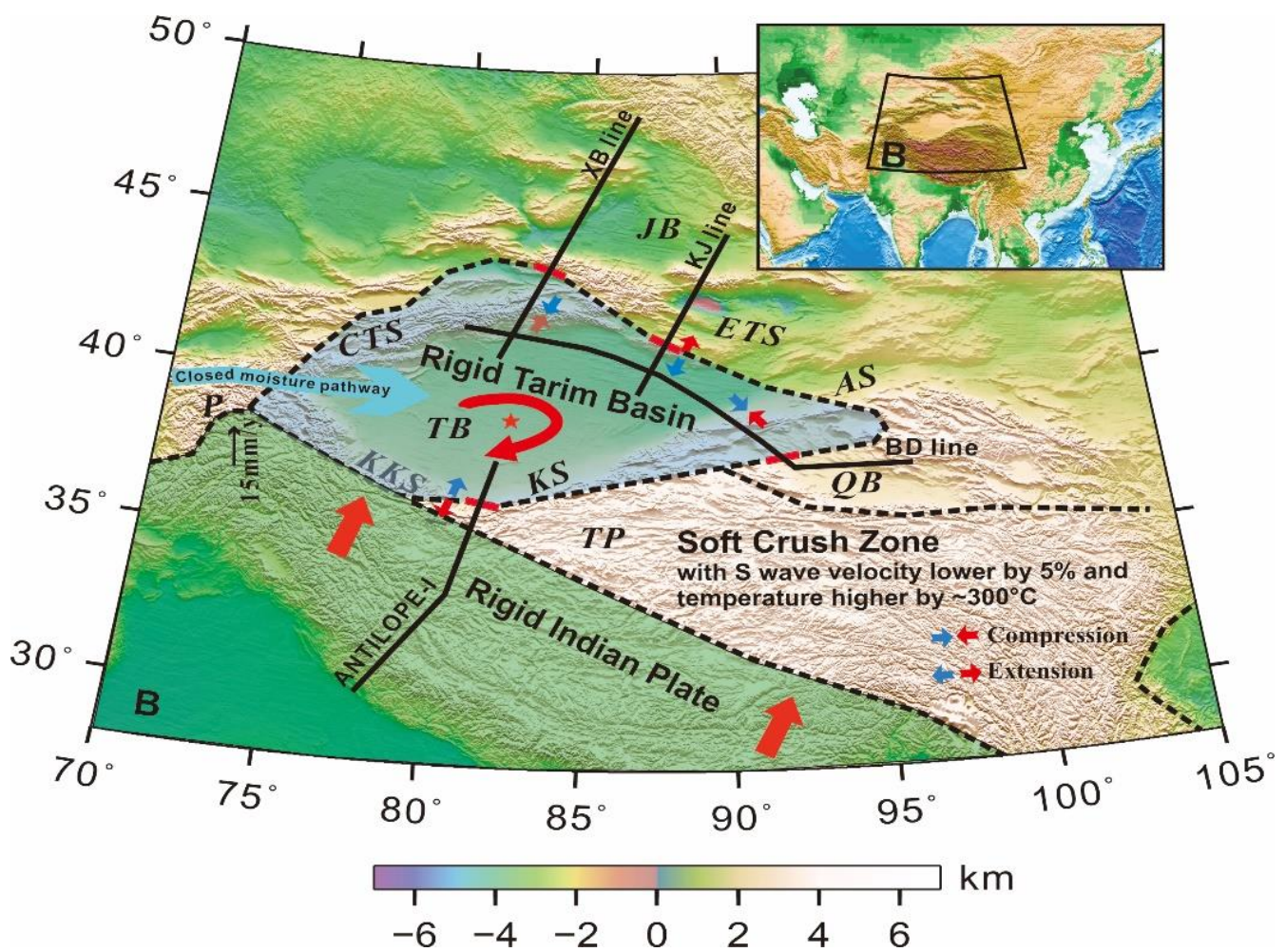

Fig. S9. Plate tectonics of western China

The solid line represents the location of the seismic section. The shaded region highlights the locations of the rigid Tarim plate, the Indian plate, and the giant crush zone (the Tibetan "plate") (the lithospheric mantle) as determined by the seismic wide-angle reflection / refraction profile [1, 2], the receiver function [3], and seismic tomography [6].

The thick red line at the edge of the Tarim basin represents the lithosphere outer margin of the Tarim plate along four sections. Blue and red arrow pairs represent compression or extension stress environments.

The red star indicates the position of the Euler pole, around which the Tarim plate rotates regularly

TB - Tarim Basin; JB - Junggar Basin; CTS - Central Tianshan; ETS - East Tianshan; P - Pamirs; AS - Altyn Tagh mountain; KS - Kunlun Mountains; KKS - Karakoram mountains;

QB - Qaidam Basin; TP - Tibetan Plateau

Puc. S9. Тектоника плит западного Китая

Сплошной линией обозначено положение сейсмического разреза. Заштрихованная область указывает местонахождение жесткой Таримской плиты, Индийской плиты и гигантской сбросовой зоны (Тибетской "плиты") (литосфрерной мантии), что было определено сейсмическим широкоугольным профилем отражения / преломления [1, 2], фуункцией приемника [3] и сейсмической томографрией [6]. Жирная красная линия по краю Таримского бассейна обозначает внешний край литосфреры Таримской плиты по четырем участкам. Пары синих и красных стрелок обозначают напряженные области сжатия или растяжения. Красная звездочка указывает положение полюса Эйлера, вокруг которого регулярно вращается Таримская плита

TB - Таримский бассейн; JB - Джунгарский бассейн; CTS - Центральный Тянь-Шань; ETS - Восточный Тянь-Шань; P - Памир; AS - гора Алтын Таг; KS - горы Куньлунь; KKS - горы Каракорум; $Q B$ - Кайдамский бассейн; TP - Тибетское плато

Ctenodactylidae, Karakoromys decessus, Tsaganomyidae, Cyclomylus lohensis, Muridae, Cricetops dormitory, Dipodidae, Parasminthus tangingoli, Parasminthus aff. Asiaecentrali, Tatalsminthus sp., Sciuridae, Gen. et sp. Indet, Aplodontidae, Prosciurus sp., Cricetidae, Gen. et sp. Indet, Eucricetodon sp., Eucricetodon caducus, Eucricetodon asiaticus, Ulaancricetodon cf. badamae, Castoridae, Propalaeocastor irtyshensis, Creodonta, Hyaenodontidae, Hyaenodon sp.
Late Oligocene, Junggar basin [8, 9] includes the Tieersihabahe Fauna Insectivora, Erinaceidae, Amphechinus kansuensis, Amphechinus minimus, Amphechinus cf. rectus, Talpidae, Gen. et sp. indet., Soricidae, Heterosoricinae, Gen. et sp. indet., Crocidosoricinae, Gen. et sp. indet., Didymoconidae, Didymoconus sp., Chiroptera, Fam. et gen. indet, Lagomorpha, Ochotonidae, Desmatolagus gobiensis, Desmatolagus sp. 1, Desmatolagus sp. 2, Sinolagomys major, Sinolagomys kansuensis, Rodentia, Ctenodactylidae, 


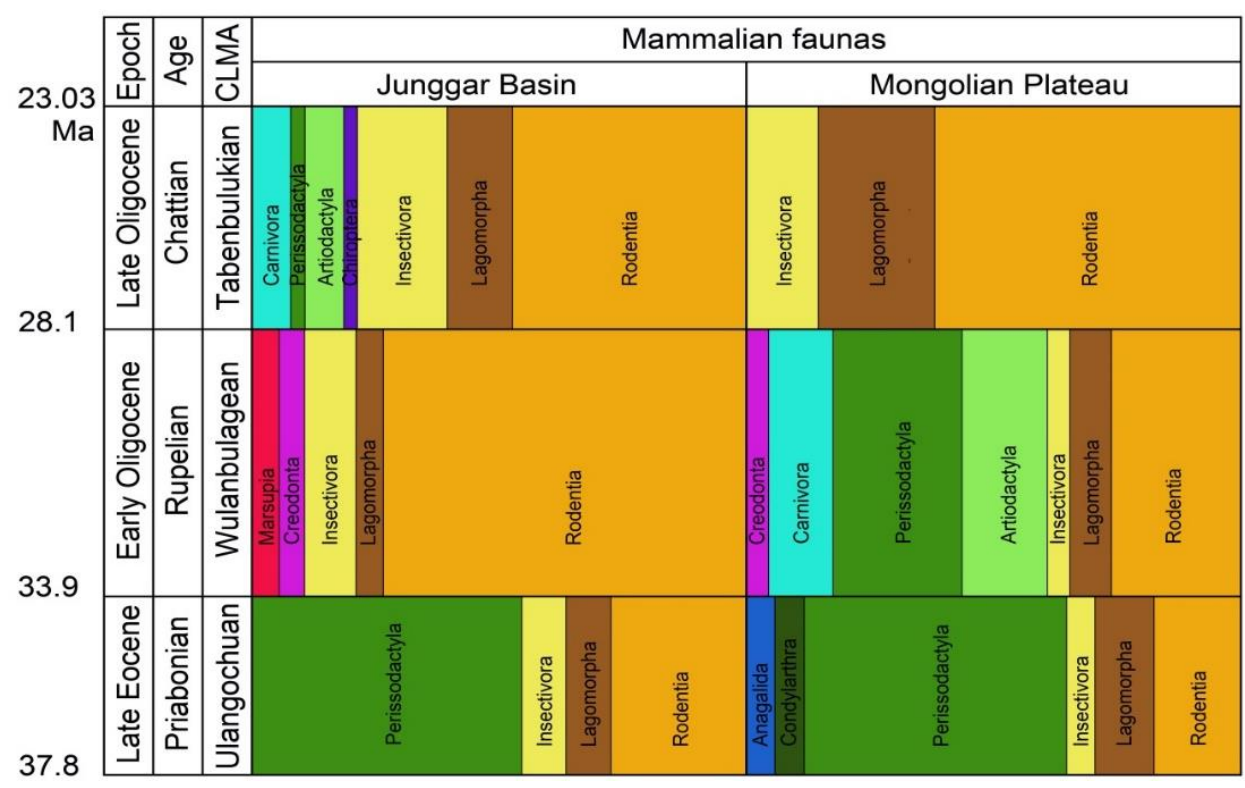

Fig. S10. Changes in faunal compositions (in percentages)

Left, a perissodactyl-dominant fauna lived in the Junggar basin during the Late Eocene, but rodents and lagomorphs had dominated the local ecosystem since the Eocene / Oligocene boundary. Right, ungulates including perissodactyls and artiodactyls were the main members of the Late Eocene and Early Oligocene mammalian faunas in the Mongolian plateau, while rodents and lagomorphs expanded their distribution until the Late Oligocene CLMA - Chinese Land Mammal Age

Puc. S10. Изменения в составе фауны (в процентах)

Слева: фрауна с преобладанием непарнокопытных животных, которые обитали в Джунгарском бассейне в позднем эоцене, с доминированием грызунов и зайцеобразных в местной экосистеме с конца эоцена начала олигоцена. Справа: копытные животные, включая непарнокопытных и парнокопытных, которые были основными представителями фрауны млекопитающих позднего эоцена и раннего олигоцена на Монгольском плато; грызуны и зайцеобразные продолжили свое распространение до позднего олигоцена CLMA - кайнозой на территории Китая

Yindirtemys cf. deflexus, Yindirtemys ambiguous, Cricetidae, Tachyoryctoides obrutschewi, Eucricetodon sp., Dipodidae Parasminthus asiaecentralis, Parasminthus tangingoli, Bohlinosminthus parvulus, Plesiosminthus sp., Litodonomys sp. 1, Litodonomys sp. 2, Litodonomys sp. 3, Litodonomys sp. 4, Litodonomys sp. 5, Aplodontidae, Ansomyinae, Gen. et sp. indet., Sciuridae, Eutamias sp., Gen. et sp. indet., Eomyidae, Pseudotheridomys asiaticus, Gliridae, Gliruloides zhoui, Carnivora, Gen. et sp. indet. 1, Gen. et sp. indet. 2, Gen. et sp. indet. 3, Perissodactyla, Paraceratheriidae, Aralotherium sui, Artiodactyla, Cervoidea, Eumeryx sp. 1, Eumeryx sp. 2, Bovidae, Gen. et sp. indet.

Late Eocene, Mongolian plateau [9] includes the Ulan Gochu Fauna Insectivora, Didymoconidae, Gen. et sp. indet., Lagomorpha, Ochotonidae, Desmotolagus vetustus, Leporidae, Gobiolagus andrewsi, Rodentia, Ischyromyidae, Gen. et $\mathrm{sp}$. indet., Hulgana ertinia, Cylindrodontidae, Ardynomys sp., Anagalida, Anagalidae, Anagale gobiensis, Condylarthra, Mesonychidae, Mongolestes hadrodens, Perissodactyla, Brontotheriidae, Metatitan primus, Metatitan progressus, Embolotherium granger, Embolotherium loucksii, Embolotherium andrewsi, Amynodontidae, Gen. et sp. indet., Amynodontopsis sp., Cadurcodon sp., Zaisanamynodon? sp.

Early Oligocene, Mongolian plateau [10, 11] includes the Wulanbulage Fauna Insectivora, Fam. et gen. indet., Lagomorpha, Ochotonidae, Desmotolagus gobiensis, Leporidae indet., Gen. et sp. indet., Rodentia, Ctenodactylidae, Karakoromys decessus, Tataromys sigmodon, Dipodidae, Plesiosminthus tangingoli, Tsaganomyidae, Tsaganomys sp., Cyclomylus lohensis, Muridae, Cricetops dormitory, Creodonta, Hyaenodontidae, Hyaenodon sp., Carnivora, Miacidae, Gen. et sp. indet., Fam. et gen. indet., Amphicyonidae, Amphicyon sp., Perissodactyla, Tapiroidea, Fam. et gen. indet., Chalicotheriidae, Schizotherium sp., Paraceratheriidae, Paraceratherium lepidum, Amynodontidae, Cadurcodon 
ardynensis, Rhinocerotidae, Aprotodon sp., Gen. et sp. indet., Artiodactyla, Cervoidea, Eumeryx sp., Lophiomerycidae, Lophiomeryx sp., Lophiomeryx gobiae, Bovidae, Gen. et sp. indet.

Late Oligocene, Mongolian plateau $[9,10]$ includes the Yikebulage Fauna Insectivora, Erinaceidae, Amphechinus cf. rectus, Amphechinus minimus, Amphechinus sp., Lagomorpha, Ochotonidae, Desmatolagus sp., Sinolagomys gracilis, Sinolagomys kansuensis, Sinolagomys major, Sinolagomys sp., Rodentia, Ctenodactylidae, Distylomys qianlishanensis, Tataromys parvus, Yindirtemys ambiguous, Yindirtemys deflexus, Yindirtemys granger, Yindirtemys suni, Yindirtemys sp., Dipodidae, Plesiosminthus parvulus, Plesiosminthus tangingoli, Muridae, Tachyoryctoides kokonorensis, Tachyoryctoides obrutschewi, Tsaganomyidae, Tsaganomys sp., Castoridae, Gen. et sp. indet.

\section{References}

1. Zhao J, Liu G, Lu Z, Zhang X, Zhao G. Lithospheric structure and dynamic processes of the Tianshan orogenic belt and the Junggar basin. Tectonophysics. 2003;376: 199-239. https://doi.org/10.1016/j.tecto.2003.07.001

2. Zhao J, Mooney WD, Zhang X, Li Z, Jin Z, Okaya N. Crustal structure across the Altyn Tagh Range at the northern margin of the Tibetan plateau and tectonic implications. Earth and Planetary Science Letters. 2006;241:804-814. https://doi.org/10.1016/j.epsl.2005.11.003

3. Zhao J, Yuan X, Liu H, Kumar P, Pei S, Kind R, et al. The boundary between the Indian and Asian tectonic plates below Tibet. Proceedings of the National Academy of Sciences of the United States of America. 2010;107: 11229-11233. https://doi.org/10.1073/pnas.1001921107

4. Li Q, You X, Yang S, Du R, Qiao X, Zou R, et al. A precise velocity field of tectonic deformation in China as inferred from intensive GPS observations. Science China Earth Sciences. 2012;55(5):695-698. https://doi.org/ 10.1007/s11430-012-4412-5

5. Zubovich AV, Wang X, Scherba YG, Schelochkov GG, Reilinger R, Reigber C, et al. GPS velocity field for the Tien Shan and surrounding regions. Tectonics. 2010;29:123. https://doi.org/10.1029/2010TC002772
6. Li C, van der Hilst RD, Meltzer AS, Engdahl ER. Subduction of the Indian lithosphere beneath the Tibetan Plateau and Burma. Earth and Planetary Science Letters. 2008;274:157-168. https://doi.org/10.1016/j.epsl.2008.07.016

7. Sun J, Ni X, Bi S, Wu W, Ye J, Meng J, et al. Synchronous turnover of flora, fauna, and climate at the Eocene-Oligocene Boundary in Asia. Scientific Reports. 2014;4:7463. https://doi.org/10.1038/srep07463

8. Ye J, Wu W, Ni X, Bi S, Sun J, Meng J. The Duolebulejin section of northern Junggar basin and its stratigraphic and environmental implication. Science China: Earth Sciences. 2012;42:1523-1532.

9. Meng J, McKenna MC. Faunal turnovers of Palaeogene mammal from the Mongolian Plateau. Nature. 1998;394:364-367. https://doi.org/10.1038/28603

10. Wang B, Chang J, Meng X, Chen J. Stratigraphy of the Upper and Middle Oligocene of Qianlishan district, Nei Mongol (Inner Mongolia). Vertebrata PalAsiatica. 1981;19:26-34.

11. Qiu Z, Wang B. Paracerathere fossils of China. Palaeontologia Sinica, New Series. 2007;29:1-396.

\section{Список литературы}

1. Zhao J., Liu G., Lu Z., Zhang X., Zhao G. Lithospheric structure and dynamic processes of the Tianshan orogenic belt and the Junggar basin // Tectonophysics. 2003. Vol. 376. P. 199-239. https://doi.org/10.1016/j.tecto. 2003.07.001

2. Zhao J., Mooney W.D., Zhang X., Li Z., Jin Z., Okaya N. Crustal structure across the Altyn Tagh Range at the northern margin of the Tibetan plateau and tectonic implications // Earth and Planetary Science Letters. 2006. Vol. 241. P. 804-814. https://doi.org/10.1016/j.epsl.2005. 11.003

3. Zhao J., Yuan X., Liu H., Kumar P., Pei S., Kind R., et al. The boundary between the Indian and Asian tectonic plates below Tibet // Proceedings of the National Academy of Sciences of the United States of America. 2010. Vol. 107. P. 11229-11233. https://doi.org/10.1073/pnas. 1001921107

4. Li Q., You X., Yang S., Du R., Qiao X., Zou R., et al. A precise velocity field of tectonic deformation in China as inferred from intensive GPS observations // Science
China Earth Sciences. 2012. Vol. 55. Iss. 5. P. 695-698. https://doi.org/10.1007/s11430-012-4412-5

5. Zubovich A.V., Wang X., Scherba Y.G., Schelochkov G.G., Reilinger R., Reigber C., et al. GPS velocity field for the Tien Shan and surrounding regions /I Tectonics. 2010. Vol. 29. P. 1-23. https://doi.org/10.1029/ 2010TC002772

6. Li C., van der Hilst R.D., Meltzer A.S., Engdahl E.R. Subduction of the Indian lithosphere beneath the Tibetan Plateau and Burma // Earth and Planetary Science Letters. 2008. Vol. 274. P. 157-168. https://doi.org/10.1016/j.epsl. 2008.07.016

7. Sun J., Ni X., Bi S., Wu W., Ye J., Meng J., et al. Synchronous turnover of flora, fauna, and climate at the Eocene-Oligocene Boundary in Asia // Scientific Reports. 2014. Vol. 4. P. 7463. https://doi.org/10.1038/srep07463

8. Ye J., Wu W., Ni X., Bi S., Sun J., Meng J. The Duolebulejin section of northern Junggar basin and its stratigraphic and environmental implication // Science China: Earth Sciences. 2012. Vol. 42. P. 1523-1532. 
9. Meng J., McKenna M.C. Faunal turnovers of Palaeogene mammal from the Mongolian Plateau // Nature. 1998. Vol. 394. P. 364-367. https://doi.org/10.1038/28603

10. Wang B., Chang J., Meng X., Chen J. Stratigraphy of the Upper and Middle Oligocene of Qianlishan district,
Nei Mongol (Inner Mongolia) // Vertebrata PalAsiatica. 1981. Vol. 19. P. 26-34.

11. Qiu Z., Wang B. Paracerathere fossils of China // Palaeontologia Sinica, New Series. 2007. Vol. 29. P. 1-396.

\section{Information about the author / Сведения об авторе}

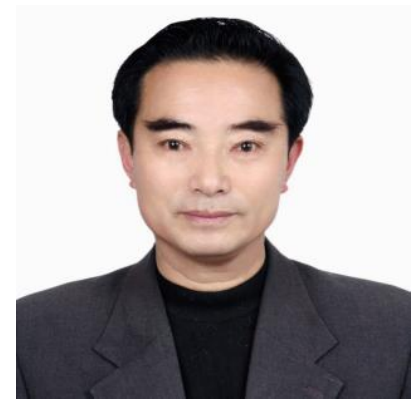

Junmeng Zhao,

Key Laboratory of Continental Collision and Plateau Uplift,

Institute of Tibetan Plateau Research, Chinese Academy of Sciences,

Beijing 100085, China

$\triangle$ e-mail: zhaojm@itpcas.ac.cn

Чжао Цзюньмэн,

Главная лаборатория континентальной коллизии и подъема Плато,

Институт изучения Тибетского плато, Китайская академия наук,

100085, г. Пекин, Китай,

$\triangle$ e-mail: zhaojm@itpcas.ac.cn

\section{Contribution of the author / Заявленный вклад автора}

The author performed the research, made a generalization on the basis of the results obtained and prepared the copyright for publication.

Автор выполнил исследовательскую работу, на основании полученных результатов провел обобщение, подготовил рукопись к печати.

\section{Conflict of interests / Конфликт интересов}

Автор заявляет об отсутствии конфликта интересов.

The author declares no conflicts of interests.

Автор прочитал и одобрил окончательный вариант рукописи.

The final manuscript has been read and approved by the author.

\section{Information about the article / Информация о статье}

The article was submitted 08.09.2020; approved after reviewing 14.10.2020; accepted for publication 16.11.2020.

Статья поступила в редакцию 08.09.2020; одобрена после рецензирования 14.10.2020; принята к публикации 16.11.2020. 